\section{Responses of Ornamental Grass and Grasslike Plants to Saline Water Irrigation}

\author{
Youping Sun ${ }^{1}$ and Alyssa Lanae Palmer
}

ADDITIONAL INDEX WORDS. salt tolerance, reclaimed water, blue grama, fox sedge, indian sea oats, common rush, sand ryegrass, pink muhly grass, fountain grass

SUMMARY. Ornamental grasses are popular in urban landscapes in Utah and the Intermountain West United States, one of the driest and fastest growing regions in the United States. This experiment evaluated the responses of five ornamental grass species [blue grama (Bouteloua gracilis), indian sea oats (Chasmanthium latifolium), 'Blue Dune' sand ryegrass (Leymus arenarius), pink muhly grass (Mublenbergia capillaris), 'Foxtrot' fountain grass (Pennisetum alopecuroides)] and two ornamental grasslike species [fox sedge (Carex vulpinoidea), common rush (Juncus effusus)] to saline irrigation water in a greenhouse. Plants were irrigated weekly with a nutrient solution at an electrical conductivity (EC) of $1.2 \mathrm{dS} \cdot \mathrm{m}^{-1}$ (control) or saline solutions at an EC of 5.0 or $10.0 \mathrm{dS} \cdot \mathrm{m}^{-1}$. At the first harvest ( 9 weeks after the initiation of treatment), sand ryegrass, pink muhly grass, and fountain grass irrigated with solutions at an EC of 5.0 and $10 \mathrm{dS} \cdot \mathrm{m}^{-1}$ had good visual quality with no or minimal foliar salt damage; however, the remaining species exhibited slight or moderate foliar salt damage. There were no significant differences in shoot dry weight (DW) among treatments within any species, except fox sedge and fountain grass. At the second harvest (18 weeks after the initiation of treatment), sand ryegrass, pink muhly grass, and fountain grass still had no or minimal foliar salt damage, and indian sea oats and fox sedge exhibited slight or moderate foliar salt damage. Compared with the control, all species irrigated with solutions at an EC of $10.0 \mathrm{dS} \cdot \mathrm{m}^{-1}$ had reduced shoot DWs with the exception of blue grama. However, only common rush and pink muhly grass irrigated with solutions at an EC of 5.0 $\mathrm{dS} \cdot \mathrm{m}^{-1}$ had lower shoot DWs than the control. These results demonstrated that seven ornamental grass or grasslike species had a very strong tolerance to the salinity levels used in the 4-month experiment. Although plant growth was inhibited as a result of saline irrigation, plant visual quality of sand ryegrass, pink muhly grass, and fountain grass was still acceptable. These three species appear to be more suitable for landscapes in which saline irrigation water is used. Further research is needed to evaluate more ornamental grasses for landscapes in salt-prone areas and nearby coastal regions.

Department of Plants, Soils and Climate, Utah State University, 4820 Old Main Hill, Logan, UT 84322

This research was supported in part by the U.S. Department of Agriculture (USDA) National Institute of Food and Agriculture Hatch project UTA01381, New Faculty Start-up Funds from the Office of Research and Graduate Studies, the Center for Water-Efficient Landscaping at Utah State University. This research was also supported by the Utah Agricultural Experiment Station, Utah State University, and approved as journal paper no. 9112 .

We are grateful for the in-kind support of plant materials from Hoffman Nursery (Rougemont, NC); technical assistance from undergraduate student Nathan Snow and visiting scholar Dr. Liqin Li; help with statistical analysis from Dr. Xin Dai, Statistician, Utah Agricultural Experiment Station; and valuable comments from anonymous reviewers.

The content is solely the responsibility of the authors and does not necessarily represent the official views of the funding agencies. Mention of a trademark, proprietary product, or vendor does not constitute a guarantee or warranty of the product by the USDA and the American Society for Horticultural Science, and does not imply its approval to the exclusion of other products or vendors that also may be suitable.

${ }^{1}$ Corresponding author. E-mail: youping.sun@usu. edu.

https://doi.org/10.21273/HORTTECH04159-18
W ater scarcity is a major concern in Utah and the Intermountain West United States, one of the driest and fastest growing regions in the United States. Climate and human-driven changes in water quantity and quality could result in more restrictions on agricultural and landscape irrigation, a segment of water use that accounts for $82 \%$ of freshwater resources in Utah (Strong et al., 2010). Therefore, water conservation is becoming critically important throughout Utah and the Intermountain West. Alternative water sources such as treated and reclaimed sewage effluent (reclaimed water) are important for landscape irrigation, with an established use record on golf courses in Utah and a handful of large corporate and municipal parks and landscapes in the arid to semiarid urban areas across the southwestern United States (Tanji et al., 2008). However, these water sources are still underused. This may be attributed to the high level of salinity and undesirable specific ions in reclaimed water that can potentially stress and damage landscape plants (Grieve, 2011). Proper management is needed to reduce salinity stress-for example, monitoring salt concentration in reclaimed water, improving drainage, maintaining a leaching fraction, and using salt-tolerant species (Niu and Cabrera, 2010). Selecting and using salt-tolerant plants are one of the best practices for preventing salt damage on landscape plants and maintaining aesthetically appealing landscapes. Previous research has documented consistently that landscape plant species and/or cultivars show different responses to salinity stress (Niu and Cabrera, 2010; Niu et al., 2011; Wu and Dodge, 2005). There is an urgent need for researchbased information on the salinity tolerance of landscape plants for use in landscapes irrigated with reclaimed water or in salt-prone areas.

Ornamental grasses have recently received considerable attention in the U.S. green industry. Their production and landscape use has expanded during the past two decades. An estimated $\$ 158$ million worth of

\begin{tabular}{llll}
\hline $\begin{array}{l}\text { Units } \\
\text { To convert U.S. to SI, } \\
\text { multiply by }\end{array}$ & U.S, unit & SI unit & $\begin{array}{l}\text { To convert SI to U.S., } \\
\text { multiply by }\end{array}$ \\
\hline 29.5735 & $\mathrm{fl} \mathrm{oz}$ & $\mathrm{mL}$ & 0.0338 \\
0.3048 & $\mathrm{ft}$ & $\mathrm{m}$ & 3.2808 \\
0.0283 & $\mathrm{ft}^{3}$ & $\mathrm{~m}^{3}$ & 35.3147 \\
3.7854 & gal & $\mathrm{L}$ & 0.2642 \\
2.54 & inch(es) & $\mathrm{cm}$ & 0.3937 \\
6.4516 & inch & $\mathrm{cm}^{2}$ & 0.1550 \\
1 & $\mathrm{mmho} / \mathrm{cm}$ & $\mathrm{dS} \cdot \mathrm{m}^{-1}$ & 1 \\
28.3495 & $\mathrm{oz}$ & $\mathrm{g}$ & 0.0353 \\
7.4892 & $\mathrm{oz} / \mathrm{gal}$ & $\mathrm{g} \cdot \mathrm{L}^{-1}$ & 0.1335 \\
1 & $\mathrm{ppm}$ & $\mathrm{mg} \cdot \mathrm{L}^{-1}$ & 1 \\
1 & $\mathrm{ppm}$ & $\mu \mathrm{gg} \cdot \mathrm{mL}^{-1}$ & 1 \\
$\left({ }^{\circ} \mathrm{F}-32\right) \div 1.8$ & ${ }^{\circ} \mathrm{F}$ & ${ }^{\circ} \mathrm{C}$ & $\left({ }^{\circ} \mathrm{C} \times 1.8\right)+32$
\end{tabular}

Hortlechnology · December 2018 28(6) 
ornamental grasses are sold annually in the United States (U.S. Department of Agriculture, 2015). Ornamental grasses are also popular in urban landscapes in Utah and the Intermountain West. Their use is expected to increase further as a result of the unique textures and patterns they contribute to the landscape, high drought tolerance, and low maintenance input (Gunnell et al., 2015). Blue grama is a warm-season perennial grass with low-growing habit, drought tolerance, and limited maintenance requirements (Wynia, 2007). It is grown in perennial gardens and is used for native plant landscaping, habitat restoration, and erosion control projects. Indian sea oats is also a warm-season perennial grass that thrives in partial shade throughout most of its range and is used as groundcover in shady areas (Neill, 2007). Sand ryegrass is a bright blue, coolseason ornamental grass with strawcolored seed heads on stalks 8 to 12 inches above the foliage. It is a sandloving grass species and can adapt easily to a highly salinized area (St. John et al., 2010). Pink muhly grass is a warm-season, hedgelike perennial with green leaves in dense clumps and pink flowers held above the foliage. It is an excellent garden plant because of its hardiness and drought tolerance, low maintenance needs, and general beauty (Kirk and Belt, 2010). Fountain grass is a warm-season; fine-textured; mounding perennial grass with narrow, medium- to deep-green leaves; and showy, silvery to pinkish white, bristly, bottlebrushlike flower spikes. Typically, it grows in spreading clumps and needs full sun to light shade (Gilman, 1999). These five species belong to the grass family (Poaceae). Fox sedge is a grasslike species in the sedge family (Cyperaceae) with an inflorescence consisting of a dense, tangled cluster of flower spikes. It tolerates fluctuating water levels and periods of drying (Wennerberg, 2004). Common rush is a grasslike perennial in the rush family (Juncaceae) with a smooth, cylindrical stem. It is cultivated as an ornamental plant for use in water gardens, native plant and wildlife gardens, and for larger designed natural landscaping and habitat restoration projects (U.S. Department of Agriculture, 2002).

Salt tolerance has been evaluated on many grasses used for turf and forage (Bushman et al., 2016; Miyamoto,
2008; Tomar et al., 2003). Warm-season grasses are usually more salt tolerant than cool-season grasses when irrigated with impaired waters (Schiavon et al., 2012, 2014). The salinity tolerance of ornamental grasses has also been reported in extension articles. For example, blue grama exhibited moderate tolerance to salinity levels at a saturated soil extract $\left(\mathrm{EC}_{\mathrm{e}}\right.$ ) of 4 to $8 \mathrm{dS} \cdot \mathrm{m}^{-1}$ (Kratsch et al., 2008). Indian sea oats, 'Glaucus' sand ryegrass, and fountain grass have high levels of tolerance to soil salinity (Jull, 2009). Sand ryegrass and pink muhly grass are highly tolerant to salt spray, and fountain grass is slightly tolerant to salt spray (Glen, 2004). However, these reports are usually based on anecdotal observations. Furthermore, there are only a few ornamental grasses being investigated systematically for salinity tolerance. Zhang et al. (2012) reported that salinity tolerance of blue grama varied within ecotypes and was greater at the germination stage than the mature stage. Pink muhly grass was tolerant of saline irrigation, with $100 \%$ of plants surviving even at sodium chloride $(\mathrm{NaCl})$ irrigation rates of $10,000 \mathrm{mg} \cdot \mathrm{L}^{-1}$, which is up to 20 times greater than what could be expected from graywater (Christova-Boal et al., 1996; LeCompte et al., 2016). 'Hameln' fountain grass appears to be slightly more tolerant of salt spray than 'Gracillimus' maiden grass [Miscanthus sinensis (Alvarez, 2006)]. Kikuyugrass (Pennisetum clandestinum) is salt tolerant, with a threshold $\mathrm{EC}_{\mathrm{e}}$ of $8.0 \mathrm{dS} \cdot \mathrm{m}^{-1}$ (Grieve et al., 2012) and shows promise as a suitable candidate for the saline-sodic water reuse system (Grieve et al., 2004). As a result of the vast number of ornamental grass and grasslike plants commercially available in the green industry and a diversified salinity tolerance in ornamental grasses commonly planted in urban landscapes, there is a need to evaluate ornamental plants further for salt tolerance for landscape use. This study was designed to compare the growth of seven ornamental grass and grasslike species in response to irrigation with saline solutions.

\section{Materials and methods}

Plant MATERIALS AND growing CONDITIONS. On 5 Oct. 2017, rooted cuttings in 32 -cell trays $(5.5 \times 5.5 \times$ $10.5 \mathrm{~cm}$ ) of five ornamental grass species (blue grama, indian sea oats, 'Blue Dune' sand ryegrass, pink muhly grass, and 'Foxtrot' fountain grass) and two grasslike species (fox sedge, common rush) were received from Hoffman Nursery (Rougemont, NC). Plants $(\approx 4$ inches tall) were potted in l-gal, injection-molded, polypropylene containers (PClD-4; Nursery Supplies, Orange, CA) filled with a soilless growing substrate consisting of $75 \%$ peatmoss (Canadian sphagnum peatmoss; SunGro Horticulture, Agawam, MA), 25\% vermiculite (Therm-O-Rock West, Chandler, $\mathrm{AZ}$ ), and $24.3 \mathrm{~g} / \mathrm{ft}^{3}$ white athletic field-marking gypsum (92\% calcium sulfate dihydrate, $21 \%$ calcium, $17 \%$ sulfur; Western Mining and Minerals, Bakersfield, CA). The water capacity of the substrate mixture was $74 \%$.

All plants were grown in a greenhouse in Logan, UT (lat. $41^{\circ} 45^{\prime} 28^{\prime \prime} \mathrm{N}$, long. $111^{\circ} 48^{\prime} 47$ "W; elevation, $1409 \mathrm{~m}$ ), and were well irrigated with tap water $\left(\mathrm{EC}=0.37 \mathrm{dS} \cdot \mathrm{m}^{-1} ; \mathrm{pH}=8.25\right)$ until treatments started. The sodium adsorption ratio (SAR) of the tap water is 0.04 , and the major ions in the tap water were calcium $\left(\mathrm{Ca}^{2+}\right)$, magnesium $\left(\mathrm{Mg}^{2+}\right)$, silicate $\left(\mathrm{SiO}_{3}{ }^{2-}\right)$, sulfate $\left(\mathrm{SO}_{4}{ }^{2-}\right)$, boron $\left(\mathrm{B}^{+}\right)$, and copper $\left(\mathrm{Cu}^{2+}\right)$ at $48.1,14.6,11.4$, $5.8,4.3$, and $3.2 \mathrm{mg} \cdot \mathrm{L}^{-1}$, respectively. The average air temperature in the greenhouse was $22.5 \pm 4.9^{\circ} \mathrm{C}$ during the day and $20.8 \pm 5.3^{\circ} \mathrm{C}$ at night. The average daily light integral inside the greenhouse was $11.8 \pm 6.2 \mathrm{~mol} \cdot \mathrm{m}^{-2} \cdot \mathrm{d}^{-1}$ during the experiment. When light intensity inside the greenhouse was less than 544 $\mu \mathrm{mol} \cdot \mathrm{m}^{-2} \cdot \mathrm{s}^{-1}$, supplemental light at light intensities of $223 \pm 37 \mu \mathrm{mol} \cdot \mathrm{m}^{-2} \cdot \mathrm{s}^{-1}$ at the canopy level was provided using 1000-W high-pressure sodium lamps (Hydrofarm, Petaluma, CA) from 600 to $2200 \mathrm{HR}$.

Treatments. A nutrient solution at an EC of $1.2 \mathrm{dS} \cdot \mathrm{m}^{-1}$ was prepared by adding $0.8 \mathrm{~g} \cdot \mathrm{L}^{-1} 15 \mathrm{~N}-$ 2.2P-12.5K water-soluble fertilizer (Peters Excel 15-5-15 Ca-Mag Special; ICL Specialty Fertilizers, Dublin, $\mathrm{OH})$ to the tap water and was used as the control. Saline solution at an EC of $5.0 \mathrm{dS} \cdot \mathrm{m}^{-1}$ was prepared by adding $0.92 \mathrm{~g} \cdot \mathrm{L}^{-1} \mathrm{NaCl}$ and $0.88 \mathrm{~g} \cdot \mathrm{L}^{-1} \mathrm{cal}-$ cium chloride $\left(\mathrm{CaCl}_{2}\right)$ to the aforementioned nutrient solution, and saline solution at an EC of 10.0 $\mathrm{dS} \cdot \mathrm{m}^{-1}$ was prepared by adding 2.27 $\mathrm{g} \cdot \mathrm{L}^{-1} \mathrm{NaCl}$ and $2.18 \mathrm{~g} \cdot \mathrm{L}^{-1} \mathrm{CaCl}_{2}$ to the nutrient solution. The SARs were 4.88 and 8.42 for the saline solutions 
with ECs of 5.0 and $10.0 \mathrm{dS} \cdot \mathrm{m}^{-1}$, respectively. This mixture was used because $\mathrm{NaCl}$ is the common salt in reclaimed water (Niu and Cabrera, 2010) and $\mathrm{CaCl}_{2}$ is used to forestall potential calcium deficiencies (Carter and Grieve, 2006). The $\mathrm{pH}$ of all solutions was adjusted to $6.5 \pm 0.2$ using nitric acid. Both control and saline solutions were prepared in 100L tanks, with EC confirmed using an EC meter (LAQUA Twin; Horiba, Kyoto, Japan) before irrigation.

Five weeks after transplanting (10 Nov. 2017), plants were fully established with roots observed visually at the root ball's periphery, and uniform plants were chosen for the experiment. From 10 Nov. 2017 to 3 Jan. 2018, treatment solutions were applied once per week for 8 weeks. At each irrigation, plants were irrigated with $1 \mathrm{~L}$ treatment solution per plant, resulting in a leaching fraction of $\approx 35.0 \pm 9.9 \%$. Between treatment solution irrigations, plants were irrigated with $300 \mathrm{~mL}$ nutrient solution whenever the substrate surface $(\approx 1$ inch) became dry. Irrigation frequency varied with environmental conditions and treatment solution. Plants at greater salinity need less irrigation because of lower water use resulting from reduced transpiration and leaf area. On 12 Jan. 2018 (9 weeks after the initiation of treatment), five plants of each species were harvested (first harvest). On 24 Jan., the remaining five plants were repotted into 2-gal, injection-molded polypropylene containers (No. 2B, Nursery Supplies) with the fresh substrate mentioned earlier because they outgrew the 1-gal containers. Four vertical cuts were made along the root ball whenever circling roots had formed. From 27 Jan. to 16 Mar. 2018 , treatment solutions were then applied once per week for 8 weeks. A total of $1.5 \mathrm{~L}$ treatment solution irrigated each plant each time, resulting in a leaching fraction of $\approx 13.4 \pm$ $7.8 \%$. On 24 Mar. (18 weeks after the initiation of treatment), all plants were harvested (second harvest). Abamectin Avid $^{\circledR}$ 0.15EC; Syngenta Crop Protection, Greensboro, NC) was sprayed to control aphids (Aphidoidea) as needed.

Leachate EC. The pourthrough method described by Cavins et al. (2008) and Wright (1986) was used to determine leachate EC. In brief, a saucer was placed under the container, which has drained for at least $30 \mathrm{~min}$ right after treatment solution was applied. A total of 100 $\mathrm{mL}$ distilled water was poured on the surface of the substrate to obtain leachate in the saucer. The leachate solution was tested using an EC meter. One plant per treatment per species was chosen for measurement. Leachate EC readings were averaged across species.

Plant growth. Plant height (measured in centimeters) from the soil surface to the tip of the tallest leaf and the number of inflorescences were recorded at both harvest dates (12 Jan. and 24 Mar.). At each harvest date, plant shoots of five plants per treatment per species were severed at the substrate surface, and leaf area was determined using an area meter (LI3100 ; LI-COR ${ }^{\circledR}$ Biosciences, Lincoln, NE). Plant shoots were dried in an oven at $70^{\circ} \mathrm{C}$ for $3 \mathrm{~d}$, and shoot DW was determined. At the second harvest date, tillers were counted. In addition, roots were cleaned and dried in the oven at $70{ }^{\circ} \mathrm{C}$ for $3 \mathrm{~d}$, and root DW was taken.

FOLIAR SALT DAMAGE EVALUATION. Foliar salt damage was rated by giving a visual score based on a reference scale from 0 to 5 , where $0=$ dead; 1 = over $90 \%$ foliar damage (salt damage: leaf edge burn, necrosis, and discoloration); $2=$ moderate ( $50 \%$ to $90 \%$ ) foliar damage; 3 = slight $(<50 \%)$ foliar damage; $4=$ good quality with minimal foliar damage; and $5=$ excellent quality with no foliar damage (Sun et al., 2015). The foliar salt damage rating did not consider plant size.

Chlorophyll content. Relative chlorophyll content [Soil-Plant Analysis Development (SPAD) reading] was measured using a handheld chlorophyll meter (SPAD 502 Plus; Minolta Camera Co., Osaka, Japan) I week before each harvest date. Ten healthy and fully expanded leaves of each plant of all species were chosen for measurement, with the exception of common rush. Instead, a protocol described by Lichtenthaler and Buschmann (2001) was used to determine the chlorophyll content of common rush. In brief, fresh leaves $(\mathrm{lg})$ were ground with $10 \mathrm{~mL}$ ethanol (95\% ethyl alcohol, PharmcoAAPER; Greenfield Global USA, Brookfield, CT). The extract was centrifuged at $1300 \mathscr{g}_{\mathrm{n}}$ (Marathon $21 \mathrm{~K}$; Thermo Fisher Scientific, Waltham, MA) for $20 \mathrm{~min}$. The supernatant $(\approx 6 \mathrm{~mL})$ was then collected and stored overnight in the dark at room temperature. Samples were loaded into plastic cuvettes (PMMA; VWR International, Radnor, PA), and spectrophotometric readings at wavelengths of 470, 648.6, and 664.1 $\mathrm{nm}$ were made (BioMate 3 , Thermo Fisher Scientific). Chlorophyll a and b contents were estimated using the formula: $C_{a}$ (micrograms per milliliter $)=13.36 A_{664.1}-5.19 A_{648.6} ; C_{b}$ $($ micrograms per milliliter $)=27.43$ $A_{648.6}-8.12 A_{664.1}$. The concentration of carotenoids was calculated as follows: $C(x+c)$ (micrograms per milliliter $)=\left(1000 A_{470}-2.13 C_{a}-\right.$ $\left.97.64 C_{b}\right) / 209$. SPAD readings correlated positively with destructive chlorophyll measurements in st. augustinegrass [Stenotaphrum secondatum (Rodriguez and Miller, 2000)].

Experimental DESIgN AND STATISTICAL ANALYSIS. All plants were arranged in the greenhouse following a split-plot experimental design, with salinity levels as the main plot factor and seven species as the subplot factor. Ten plants per treatment per species were used. Because of different plant growth habits, data were analyzed separately for each species following a completely randomized experimental design with three salinity levels. Visual score was analyzed as multinomial data, whereas number of inflorescences and tillers were analyzed as negative binomial data. Means separation among treatments was adjusted using Tukey's method for multiplicity at $\alpha=0.05$. Means separation among species was also conducted for visual score. All statistical analyses were performed with the GENMOD and GLIMMIX procedures of SAS/STAT 14.3 in SAS (SAS Institute, Cary, NC).

\section{Results and discussion}

Salts gradually built up in the plant root zone when plants received saline water irrigation, as indicated by an increased salinity level in the leachate solution (Fig. 1). From 10 Nov. 2017 to 3 Jan. 2018, the EC of the leachate solution ranged from 4.1 to $8.4 \mathrm{dS} \cdot \mathrm{m}^{-1}$ and from 5.9 to 13.8 $\mathrm{d} S \cdot \mathrm{m}^{-1}$ when irrigated with solutions 
at an EC of 5.0 and $10.0 \mathrm{dS} \cdot \mathrm{m}^{-1}$, respectively. However, the EC of the leachate solution stayed around 2.0 $\mathrm{dS} \cdot \mathrm{m}^{-1}$ for the control. From 27 Jan. to 16 Mar. 2018, the EC of the leachate solution for control was from 2.4 to $3.8 \mathrm{dS} \cdot \mathrm{m}^{-1}$, with an average of $3.0 \mathrm{dS} \cdot \mathrm{m}^{-1}$. The EC of the leachate solution ranged from 6.1 to 13.5 $\mathrm{d} S \cdot \mathrm{m}^{-1}$ and from 8.6 to $20.9 \mathrm{dS} \cdot \mathrm{m}^{-1}$ when irrigated with solutions at an EC of 5.0 and $10.0 \mathrm{dS} \cdot \mathrm{m}^{-1}$, respectively. These results are similar to previous reports (Sun et al., 2015; Wu et al., 2016) that consistently documented that the salinity level in the leachate solution increased when irrigated with saline solution, and the EC of leachate was greater than that of the treatment solution after two or three irrigation events.

At the first harvest, sand ryegrass, pink muhly grass, and fountain grass exhibited no foliar salt damage when irrigated with solutions at an EC of $5.0 \mathrm{dS} \cdot \mathrm{m}^{-1}$, and they had minimal foliar salt damage with visual scores of 4.4 or greater when irrigated with solutions at an EC of $10.0 \mathrm{dS} \cdot \mathrm{m}^{-1}$ (Table 1). Common rush experienced minimal foliar salt damage, with an average visual score of 4.5 and 3.9 when irrigated with solutions at an EC of 5.0 and $10.0 \mathrm{dS} \cdot \mathrm{m}^{-1}$, respectively. Blue grama, indian sea oats, and fox sedge had slight foliar salt damage, with average visual scores ranging from 3.0 to 3.8 when irrigated with solutions at an EC of 5.0 and $10.0 \mathrm{dS} \cdot \mathrm{m}^{-1}$. At the second harvest, fountain grass and pink muhly grass still showed no foliar salt damage using solutions at an EC of $5.0 \mathrm{dS} \cdot \mathrm{m}^{-1}$ and had minimal or slight damage using solutions at an EC of $10.0 \mathrm{dS} \cdot \mathrm{m}^{-1}$. Sand ryegrass and indian sea oats experienced minimal foliar salt damage when irrigated with solutions at an EC of 5.0 and $10.0 \mathrm{dS} \cdot \mathrm{m}^{-1}$. Fox sedge plants had moderate foliar salt damage, with an average visual score of 3.0 using solutions at an EC of $5.0 \mathrm{dS} \cdot \mathrm{m}^{-1}$ and $2.4 \mathrm{using}$ solutions at an EC of $10.0 \mathrm{dS} \cdot \mathrm{m}^{-1}$. Visual scores were not assigned at the second harvest date for blue grama and common rush as a result of an aphid infestation. McKenney et al. (2016) observed that the visual quality of blue muhly grass (Mublenbergia lindbeimeri), indian sea oats, and foothill sedge (Carex tumulicola) plants were barely affected by increasing salinity until an EC of $5.0 \mathrm{dS} \cdot \mathrm{m}^{-1}$ was reached, but declined sharply at an EC of 10.0 $\mathrm{d} S \cdot \mathrm{m}^{-1}$. They also found that blue muhly grass irrigated with solutions at an EC of $10.0 \mathrm{dS} \cdot \mathrm{m}^{-1}$ still had acceptable visual quality, but indian sea oats and foothill sedge exhibited poor visual quality.

The relative chlorophyll content (SPAD reading) of all ornamental grass and grasslike plants irrigated with solutions at an EC of $5.0 \mathrm{dS} \cdot \mathrm{m}^{-1}$ was similar to that in the control at the first harvest (Table 1). Blue grama, sand ryegrass, and fountain grass irrigated with solutions at an EC of $10.0 \mathrm{dS} \cdot \mathrm{m}^{-1}$ also had similar SPAD

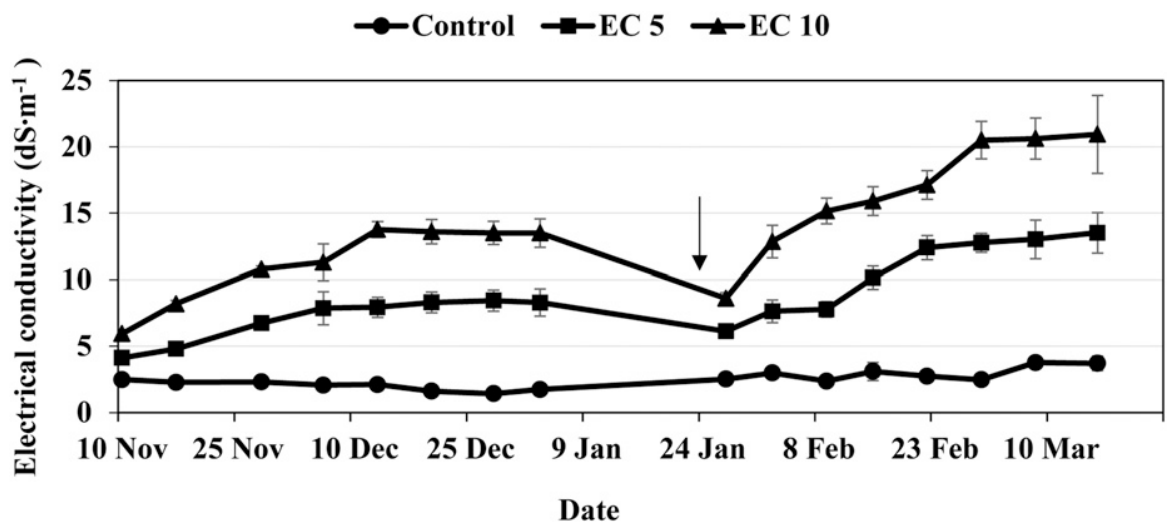

Fig. 1. Time course of the electrical conductivity (EC) of leachate solution collected after ornamental grass or grasslike species irrigated with a nutrient solution at an EC of $1.2 \mathrm{dS} \cdot \mathrm{m}^{-1}$ (control) or a saline solution at an EC of $5.0 \mathrm{dS} \cdot \mathrm{m}^{-1}$ (EC 5) or $10.0 \mathrm{dS} \cdot \mathrm{m}^{-1}$ (EC 10) in a greenhouse. One plant per treatment per species was chosen for measurement. Leachate EC readings were averaged across seven ornamental grass and grasslike species. Vertical bars represent SES of seven measurements. Arrow denotes that plants grown in 1-gal containers were repotted into 2 -gal $(7.6-\mathrm{L})$ containers. $1 \mathrm{dS} \cdot \mathrm{m}^{-1}=1 \mathrm{mmho} / \mathrm{cm}$. readings to those in the control. However, fox sedge and pink muhly grass irrigated with solutions at an EC of $10.0 \mathrm{dS} \cdot \mathrm{m}^{-1}$ had lower SPAD readings than the control. At the second harvest, blue grama, sand ryegrass, pink muhly grass, and fountain grass irrigated with solutions at an EC of $5.0 \mathrm{dS} \cdot \mathrm{m}^{-1}$ and $10.0 \mathrm{dS} \cdot \mathrm{m}^{-1}$ had similar SPAD values to the control. However, the SPAD readings of fox sedge irrigated with solutions at an EC of $5.0 \mathrm{dS} \cdot \mathrm{m}^{-1}$ and $10.0 \mathrm{dS} \cdot \mathrm{m}^{-1}$ were less than the control. Interestingly, all indian sea oats had yellowish foliage during the entire experiment. This might be attributed to greater light levels in the greenhouse because indian sea oats usually thrives in partial shade throughout most of its range and is planted in shady areas (Neill, 2007). Norcini et al. (2001) found that the foliage of indian sea oats was more yellowish when grown under full sun than when grown in the shade. The SPAD readings of indian sea oats were greater than the control when plants were irrigated with a saline solution, which might be caused by increased specific leaf weight (the weight per unit area of a leaf) under osmotic stress (Acosta-Motos et al., 2017; Caudle et al., 2014; GarcíaValenzuela et al., 2005). In common rush, the chlorophyll and carotenoid contents determined by chemical extraction and spectrophotometer were not significantly different among treatments (data not shown). These results are in line with a previous report that increasing salinity stress did not change the SPAD reading of blue muhly, indian sea oats, and foothill sedge (McKenney et al., 2016).

At the first harvest, blue grama, fox sedge, common rush, and sand ryegrass plants irrigated with solutions at an EC of $5.0 \mathrm{dS} \cdot \mathrm{m}^{-1}$ had a similar height to the control (Table 2). Nevertheless, indian sea oats, pink muhly grass, and fountain grass irrigated with solutions at an EC of 5.0 $\mathrm{dS} \cdot \mathrm{m}^{-1}$ were $26 \%, 22 \%$, and $18 \%$, respectively, shorter than those in the control. All ornamental grass and grasslike plants irrigated with solutions at an EC of $10.0 \mathrm{dS} \cdot \mathrm{m}^{-1}$ had a reduction of $10 \%$ to $38 \%$ in height compared with the control. At the second harvest, compared with the control, blue grama, fox sedge, pink muhly grass, and fountain grass irrigated with solutions at an EC of 5.0 
Table 1. Visual score and relative chlorophyll content [ soil plant analysis development (SPAD) reading] of seven ornamental grass or grasslike species irrigated with nutrient solution [electrical conductivity $\left.(\mathrm{EC})=1.2 \mathrm{dS} \cdot \mathrm{m}^{-1}(\mathrm{control})\right]$ or saline solution $\left[\mathrm{EC}=5.0 \mathrm{dS} \cdot \mathrm{m}^{-1}(\mathrm{EC} 5)\right.$ or $10.0 \mathrm{dS} \cdot \mathrm{m}^{-1}$ (EC 10)] in a greenhouse. Plants were harvested after the eighth (first harvest, 9 weeks after the initiation of treatment) and 16th (second harvest, 18 weeks after the initiation of treatment) irrigation. $^{\mathrm{z}}$

\begin{tabular}{|c|c|c|c|c|c|c|c|c|c|c|c|c|}
\hline \multirow[b]{3}{*}{ Species } & \multicolumn{6}{|c|}{ Visual score $(0 \text { to } 5 \text { scale })^{y}$} & \multicolumn{6}{|c|}{ SPAD reading } \\
\hline & \multicolumn{3}{|c|}{ First harvest } & \multicolumn{3}{|c|}{ Second harvest } & \multicolumn{3}{|c|}{ First harvest } & \multicolumn{3}{|c|}{ Second harvest } \\
\hline & Control & EC 5 & EC 10 & Control & EC 5 & EC 10 & Control & EC 5 & EC 10 & Control & EC 5 & EC 10 \\
\hline Indian sea oats & $2 \mathrm{aB}$ & $3.7 \mathrm{bC}$ & $3.0 \mathrm{cF}$ & $4.6 \mathrm{aAB}$ & $4.0 \mathrm{abB}$ & $3.8 \mathrm{bA}$ & & $19.6 \mathrm{ab}$ & $23.6 \mathrm{a}$ & $30.9 \mathrm{~b}$ & $36.9 \mathrm{a}$ & $33.0 \mathrm{~b}$ \\
\hline Fox sedge & $5.0 \mathrm{aA}$ & $3.0 \mathrm{bD}$ & $3.0 \mathrm{bF}$ & $4.0 \mathrm{aB}$ & $3.0 \mathrm{bC}$ & $2.4 \mathrm{cB}$ & $45.6 \mathrm{a}$ & $45.3 \mathrm{a}$ & $43.9 \mathrm{~b}$ & $47.2 \mathrm{a}$ & $44.4 \mathrm{~b}$ & $42.8 \mathrm{c}$ \\
\hline Common rush & aA & $4.5 \mathrm{bB}$ & $3.9 \mathrm{cD}$ & - $^{\mathrm{w}}$ & - & - & $-^{\mathrm{v}}$ & - & - & $\mathrm{-}^{\mathrm{v}}$ & - & - \\
\hline Fountain grass & $5.0 \mathrm{aA}$ & $5.0 \mathrm{aA}$ & $4.7 \mathrm{bB}$ & $5.0 \mathrm{aA}$ & $5.0 \mathrm{aA}$ & $4.0 \mathrm{bA}$ & $46.2 \mathrm{a}$ & $44.6 \mathrm{a}$ & $44.5 \mathrm{a}$ & $44.3 \mathrm{a}$ & $44.9 \mathrm{a}$ & $44.9 \mathrm{a}$ \\
\hline
\end{tabular}

${ }_{\mathrm{z}} \mathrm{ldS} \cdot \mathrm{m}^{-1}=1 \mathrm{mmho} / \mathrm{cm}$.

${ }^{\mathrm{y}} 0=$ dead; $1=$ more than $90 \%$ foliar salt damage (i.e., leaf burn, necrosis, and discoloration $) ; 2=$ moderate $(50 \%$ to $90 \%)$ foliar salt damage; $3=$ slight $(<50 \%)$ foliar salt damage; $4=$ good quality with minimal foliar salt damage; and $5=$ excellent quality without foliar salt damage.

${ }^{\mathrm{x}}$ Means with the same lowercase letters within a row and harvest date are not significantly different among treatments by Tukey's method for multiplicity at $\alpha=0.05$. For visual score, means with the same uppercase letters are not significantly different among species by Tukey's method for multiplicity at $\alpha=0.05$.

wPlants infested with aphids. Visual scores were not measured.

${ }^{\text {v} C h l o r o p h y l l ~ m e t e r ~(S P A D ~} 502$ Plus; Minolta Camera Co., Osaka, Japan) did not work on this species.

Table 2. Height and leaf area per plant of seven ornamental grass or grasslike species irrigated with nutrient solution $\left[\right.$ electrical conductivity $\left.(\mathrm{EC})=1.2 \mathrm{dS} \cdot \mathrm{m}^{-1}(\mathrm{control})\right]$ or saline solution $\left[\mathrm{EC}=5.0 \mathrm{dS} \cdot \mathrm{m}^{-1}(\mathrm{EC} 5)\right.$ or $\left.10.0 \mathrm{dS} \cdot \mathrm{m}^{-1}(\mathrm{EC} 10)\right]$ in a greenhouse. Plants were harvested after the eighth (first harvest, 9 weeks after the initiation of treatment) and 16 th (second harvest, 18 weeks after the initiation of treatment) irrigation. ${ }^{\mathrm{z}}$

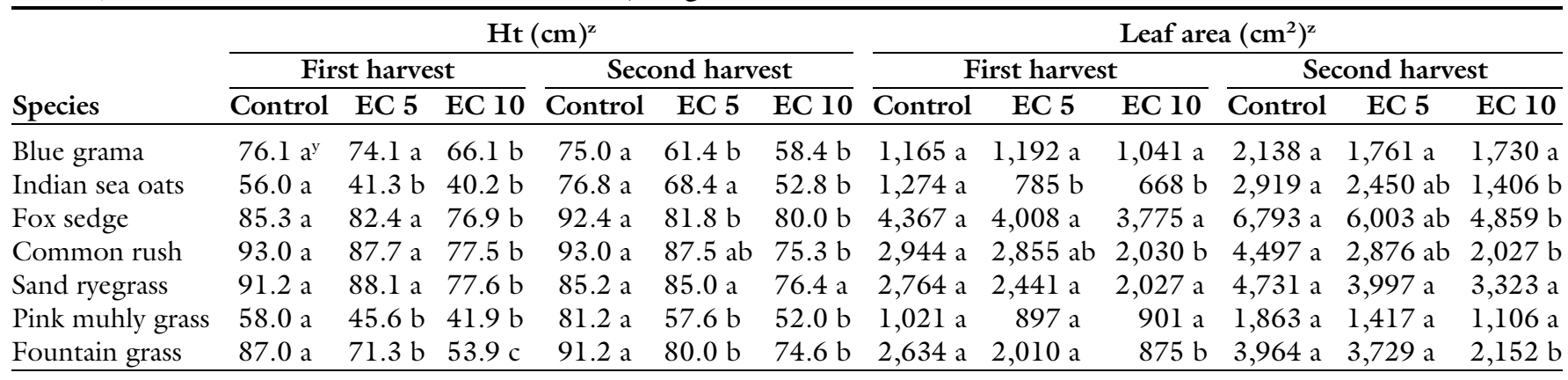

${ }^{\mathrm{z}} \mathrm{l} \mathrm{dS} \cdot \mathrm{m}^{-1}=1 \mathrm{mmho} / \mathrm{cm}, 1 \mathrm{~cm}=0.3937 \mathrm{inch}, 1 \mathrm{~cm}^{2}=0.1550 \mathrm{inch}^{2}$.

${ }^{\mathrm{y}}$ Means with the same lowercase letters within a row and harvest date are not significantly different among treatments by Tukey's method for multiplicity at $\alpha=0.05$.

$\mathrm{dS} \cdot \mathrm{m}^{-1}$ reduced their height by $18 \%$, $12 \%, 29 \%$, and $12 \%$, respectively. The height of the remaining three species irrigated with solutions at an EC of $5.0 \mathrm{dS} \cdot \mathrm{m}^{-1}$ did not differ from the control. Except for sand ryegrass, all ornamental grass and grasslike plants irrigated with solutions at an EC of $10.0 \mathrm{dS} \cdot \mathrm{m}^{-1}$ had a $13 \%$ to $36 \%$ reduction in height compared with the control. McKenney et al. (2016) documented in their research that blue muhly and foothill sedge plants irrigated with solutions at an EC of 10.0 $\mathrm{dS} \cdot \mathrm{m}^{-1}$ were much shorter than those at lower EC levels, but indian sea oats exhibited similar height among salinity treatments.

At the first harvest, all ornamental grass and grasslike plants irrigated with solutions at an EC of $5.0 \mathrm{dS} \cdot \mathrm{m}^{-1}$ had similar leaf areas to the control with the exception of indian sea oats, which had a $38 \%$ reduction (Table 2 ). The leaf areas of indian sea oats, common rush, and fountain grass irrigated with solutions at an EC of $10.0 \mathrm{dS} \cdot \mathrm{m}^{-1}$ were $48 \%, 31 \%$, and $67 \%$ less than the control, respectively. At the second harvest, there was no significant difference in the leaf area of all ornamental grass and grasslike plants irrigated with solutions at an EC of $5.0 \mathrm{dS} \cdot \mathrm{m}^{-1}$ and the control. Indian sea oats, fox sedge, common rush, and fountain grass irrigated with solutions at an EC of $10.0 \mathrm{dS} \cdot \mathrm{m}^{-1}$ had $52 \%, 29 \%, 55 \%$, and $46 \%$ smaller leaf areas, respectively, than the control. Similarly, reduction in leaf area has been observed in many plant species under salinity stress (Sun et al., 2015; $\mathrm{Wu}$ et al., 2016). This could be considered a first line of defense strategy against salt-induced drought conditions. Salinity lowers the water potential of the soil solution, thereby making water less available to plants, and reducing leaf surface area with fewer stomata could reduce water loss significantly as an adaptation to a saline environment.

Fox sedge and pink muhly grass plants did not produce any inflorescences during the entire experiment (Table 3 ). At the first harvest, all common rush and fountain grass did not form inflorescences. Indian sea oats produced less inflorescences when saline water irrigation was applied. Although the remaining two plant species produced inflorescences, there were no significant differences among treatments. At the second harvest, the number of inflorescences of blue grama, indian sea oats, and 
sand ryegrass also did not change; however, irrigation with solutions at an EC of $5.0 \mathrm{dS} \cdot \mathrm{m}^{-1}$ reduced the number of inflorescences of common rush by $50 \%$, and irrigation with solutions at an EC of $10.0 \mathrm{dS} \cdot \mathrm{m}^{-1}$ lowered the number of inflorescences of common rush and fountain grass by $89 \%$ and $48 \%$, respectively. Hunter and $\mathrm{Wu}(2005)$ observed no significant effect of salinity on flowering in native California grass species that received moderate salt spray. However, decreased flowering on 'Gracillimus' maiden grass and 'Hameln' fountain grass occurred at $100 \%$ seawater salt spray, whereas no difference in flowering was observed at $50 \%, 25 \%$, or $0 \%$ seawater salt spray (Scheiber et al., 2008). In addition, fox sedge and fountain grass irrigated with solutions at an EC of $10.0 \mathrm{dS} \cdot \mathrm{m}^{-1}$ had $26 \%$ and $23 \%$ fewer tillers, respectively, compared with their respective controls. Saline water irrigation slightly reduced the number of tillers of other tested species (Table 3 ).

At the first harvest, saline solutions at an EC of $5.0 \mathrm{dS} \cdot \mathrm{m}^{-1}$ and 10.0 $\mathrm{dS} \cdot \mathrm{m}^{-1}$ did not affect the shoot growth of all species except fox sedge and fountain grass. Fox sedge irrigated with solutions at an EC of 5.0 $\mathrm{dS} \cdot \mathrm{m}^{-1}$ and $10.0 \mathrm{dS} \cdot \mathrm{m}^{-1}$ had $16 \%$ and $17 \%$, respectively, less shoot DW than the control, whereas fountain grass irrigated with solutions at an EC of $10.0 \mathrm{dS} \cdot \mathrm{m}^{-1}$ produced $54 \%$ less shoot DW than the control (Table 4). At the second harvest, saline solutions at an EC of $5.0 \mathrm{dS} \cdot \mathrm{m}^{-1}$ and $10.0 \mathrm{dS} \cdot \mathrm{m}^{-1}$ had no influence on the shoot growth of blue grama (Table 4 ). The solution at an EC of $10.0 \mathrm{dS} \cdot \mathrm{m}^{-1}$ decreased the shoot DW of indian sea oats, fox sedge, sand ryegrass, and fountain grass by $55 \%, 29 \%, 19 \%$, and $41 \%$, respectively, but this was not the case for plants irrigated with solutions at an EC of $5.0 \mathrm{dS} \cdot \mathrm{m}^{-1}$. Both saline solutions at an EC of $5.0 \mathrm{dS} \cdot \mathrm{m}^{-1}$ and
$10.0 \mathrm{dS} \cdot \mathrm{m}^{-1}$ reduced the shoot DW of common rush by $30 \%$ and $49 \%$, respectively, and that of pink muhly grass by $28 \%$ and $43 \%$. Saline water irrigation also inhibited the root growth of fox sedge, common rush, and pink muhly grass with reductions of $35 \%, 69 \%$, and $64 \%$ for plants irrigated with solutions at an EC of $5 \mathrm{dS} \cdot \mathrm{m}^{-1}$ and of $71 \%, 77 \%$, and $80 \%$ for plants irrigated with solutions at an EC of $10 \mathrm{dS} \cdot \mathrm{m}^{-1}$, respectively (Table 4). Saline irrigation water at an EC of $10 \mathrm{dS} \cdot \mathrm{m}^{-1}$ hindered the root growth of indian sea oats and fountain grass by $57 \%$ and $59 \%$, respectively. The total DW of blue grama, indian sea oats, and fountain grass irrigated with solutions at an EC of $5.0 \mathrm{dS} \cdot \mathrm{m}^{-1}$ was not different from the controls. However, a reduction of $12 \%$ to $37 \%$ in total DW was recorded for fox sedge, common rush, sand ryegrass, and pink muhly grass plants irrigated with solutions at an EC of $5.0 \mathrm{dS} \cdot \mathrm{m}^{-1}$. All plant species except

Table 3. Number of inflorescences and number of tillers per plant of seven ornamental grass or grasslike species irrigated with nutrient solution [electrical conductivity $(\mathrm{EC})=1.2 \mathrm{dS} \cdot \mathrm{m}^{-1}$ (control)] or saline solution $\left[\mathrm{EC}=5.0 \mathrm{dS} \cdot \mathrm{m}^{-1}(\mathrm{EC} 5)\right.$ or 10.0 $\mathrm{dS} \cdot \mathrm{m}^{-1}$ (EC 10)] in a greenhouse. Plants were harvested after the eighth (first harvest, 9 weeks after the initiation of treatment) and 16th (second harvest, 18 weeks after the initiation of treatment) irrigation. ${ }^{2}$

\begin{tabular}{|c|c|c|c|c|c|c|c|c|c|}
\hline \multirow[b]{3}{*}{ Species } & \multicolumn{6}{|c|}{ Inflorescences (no.) } & \multirow{2}{*}{\multicolumn{3}{|c|}{$\begin{array}{c}\text { Tillers (no.) } \\
\text { Second harvest }\end{array}$}} \\
\hline & \multicolumn{3}{|c|}{ First harvest } & \multicolumn{3}{|c|}{ Second harvest } & & & \\
\hline & Control & EC 5 & EC 10 & Control & EC 5 & EC 10 & Control & EC 5 & EC 10 \\
\hline Indian sea oats & $3.4 \mathrm{a}$ & $1.8 \mathrm{~b}$ & $1.8 \mathrm{~b}$ & $21 \mathrm{a}$ & $18 \mathrm{a}$ & $14 \mathrm{a}$ & $47 \mathrm{a}$ & $46 \mathrm{a}$ & $35 \mathrm{a}$ \\
\hline Fox sedge & $-^{x}$ & - & - & - & - & 一 & $370 \mathrm{a}$ & $332 \mathrm{ab}$ & $275 \mathrm{~b}$ \\
\hline Common rush & - & - & - & $53.3 \mathrm{a}$ & $26.5 \mathrm{~b}$ & $6 \mathrm{c}$ & $655 a$ & $502 \mathrm{a}$ & $482 \mathrm{a}$ \\
\hline Fountain grass & - & - & - & $22 \mathrm{a}$ & $19 \mathrm{a}$ & $12 \mathrm{~b}$ & $100 \mathrm{a}$ & $90 \mathrm{ab}$ & $78 \mathrm{~b}$ \\
\hline
\end{tabular}

${ }^{\mathrm{z}} \mathrm{l} \mathrm{dS} \cdot \mathrm{m}^{-1}=1 \mathrm{mmho} / \mathrm{cm}$.

${ }^{y}$ Means with the same lowercase letters within a row and harvest date are not significantly different among treatments by Tukey's method for multiplicity at $\alpha=0.05$.

${ }^{\mathrm{x}}$ No plants flowered during the entire experimental period.

Table 4. Shoot, root, and total dry weight (DW) of seven ornamental grass or grasslike species irrigated with nutrient

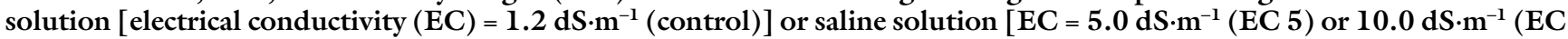
10)] in a greenhouse. Plants were harvested after the eighth (first harvest, 9 weeks after the initiation of treatment) and 16th (second harvest, 18 weeks after the initiation of treatment) irrigation. ${ }^{\mathrm{z}}$

\begin{tabular}{|c|c|c|c|c|c|c|c|c|c|c|c|c|}
\hline \multirow[b]{3}{*}{ Species } & \multicolumn{6}{|c|}{ Shoot DW $(\mathrm{g})^{\mathrm{z}}$} & \multirow{2}{*}{\multicolumn{3}{|c|}{$\begin{array}{c}\text { Root DW (g) } \\
\text { Second harvest }\end{array}$}} & \multirow{2}{*}{\multicolumn{3}{|c|}{$\begin{array}{c}\text { Total DW (g) } \\
\text { Second harvest }\end{array}$}} \\
\hline & \multicolumn{3}{|c|}{ First harvest } & \multicolumn{3}{|c|}{ Second harvest } & & & & & & \\
\hline & Control & EC 5 & EC 10 & Control & EC 5 & EC 10 & Control & EC 5 & EC 10 & Control & EC 5 & EC 10 \\
\hline Ind & & $12.4 \mathrm{a}$ & $11.0 \mathrm{a}$ & $57.1 \mathrm{a}$ & $47.0 \mathrm{ab}$ & 25 & 6 a & $13.6 \mathrm{ab}$ & $7.1 \mathrm{~b}$ & $6 \mathrm{a}$ & $60.5 \mathrm{a}$ & \\
\hline Fox sedge & $66.9 \mathrm{a}$ & $56.4 \mathrm{~b}$ & $55.5 \mathrm{~b}$ & $173.4 \mathrm{a}$ & $165.1 \mathrm{a}$ & $123.3 \mathrm{~b}$ & $50.9 \mathrm{a}$ & $33.0 \mathrm{~b}$ & $14.8 \mathrm{c}$ & $224.3 \mathrm{a}$ & $198.1 \mathrm{~b}$ & $138.2 \mathrm{c}$ \\
\hline on rush & $.7 \mathrm{a}$ & $59.1 \mathrm{a}$ & $47.7 \mathrm{a}$ & $185.6 \mathrm{a}$ & $130.7 \mathrm{~b}$ & $4 \mathrm{~b}$ & $7 \mathrm{a}$ & $4.9 \mathrm{~b}$ & $3.6 \mathrm{~b}$ & $.3 \mathrm{a}$ & $135.6 \mathrm{~b}$ & $99.0 \mathrm{~b}$ \\
\hline Fountain grass & $40.9 \mathrm{a}$ & $30.9 \mathrm{ab}$ & $19.0 \mathrm{~b}$ & $169.7 \mathrm{a}$ & $158.2 \mathrm{a}$ & $100.8 \mathrm{~b}$ & $60.4 \mathrm{a}$ & $50.0 \mathrm{a}$ & $24.5 \mathrm{~b}$ & $230.1 \mathrm{a}$ & $208.1 \mathrm{a}$ & $125.3 \mathrm{~b}$ \\
\hline
\end{tabular}

${ }^{\mathrm{z}} \mathrm{l} \mathrm{dS} \cdot \mathrm{m}^{-1}=1 \mathrm{mmho} / \mathrm{cm}, \mathrm{lg}=0.0353 \mathrm{oz}$.

${ }^{\mathrm{y}}$ Means with the same lowercase letters within a row and harvest date are not significantly different among treatments by Tukey's method for multiplicity at $\alpha=0.05$. 
blue grama had a reduction of $22 \%$ to $53 \%$ in total DW when irrigated with solutions at an EC of $10.0 \mathrm{dS} \cdot \mathrm{m}^{-1}$. These results are in agreement with a previous report (Alvarez, 2006) that the root, shoot, and whole plant biomass gain of 'Hameln' fountain grass and 'Gracillimus' maiden grass decreased as the seawater concentration increased from $0 \%$ to $100 \%$. Shoot DW of buffalograss (Buchloe dactyloides) and blue grama also declined with salinity level increasing from 0 to $10 \mathrm{~g} \cdot \mathrm{L}^{-1}$ (Zhang et al., 2012). LeCompte et al. (2016) observed that the root and shoot DW of muhly grass decreased with high $\mathrm{NaCl}$ concentrations, increasing from 2000 to $10,000 \mathrm{mg} \cdot \mathrm{L}^{-1}$, but there was no significant effect of low $\mathrm{NaCl}$ concentrations $\left(0-1000 \mathrm{mg} \cdot \mathrm{L}^{-1}\right)$ on its root and shoot DW.

This research evaluated seven ornamental grass and grasslike species for their tolerance to saline irrigation water containing $\mathrm{NaCl}$ and $\mathrm{CaCl}_{2}$ salts that could be expected from reclaimed water. Unlike many ornamental herbaceous and woody shrub species screened in the past, these ornamental grass and grasslike plants showed a very strong tolerance to the salinity levels in the 4-month greenhouse experiment. Sand ryegrass, pink muhly grass, and fountain grass plants were still of high visual quality and marketable, although their plant growth reduced as a result of saline water irrigation. These three species had minimum foliar salt damage, but the remaining tested species exhibited slight or moderate foliar salt damage. Sand ryegrass, pink muhly grass, and fountain grass appear to be more suitable for landscapes in which saline irrigation water is used. Plant responses to saline water in this research could also be applied to landscapes in salt-prone areas and nearby coastal regions.

\section{Literature cited}

Acosta-Motos, J.R., M.F. Ortuño, A. Bernal-Vicenta, P. Diaz-Vivancos, M.J. Sanchez-Blanco, and J.A. Hernandez. 2017. Plant responses to salt stress: Adaptive mechanisms. Agronomy (Basel) 7:1-38.

Alvarez, E.E. 2006. Salt and drought tolerance of four ornamental grasses. University of Florida at Gainesville, MS thesis.
Bushman, S., L. Wang, X. Dai, A. Joshi, J.G. Robins, and P.G. Johnson. 2016. Responses of tolerant and susceptible kentucky bluegrass germplasm to salt stress. J. Amer. Soc. Hort. Sci. 141:449-456.

Carter, C.T. and C.M. Grieve. 2006. Salt tolerance of floriculture crops, p. 279287. In: M.A. Khan and D.J. Weber (eds.). Ecophysiology of high salinity tolerant plants. Springer Science + Business Media, Dordrecht, The Netherlands.

Caudle, K.L., L.C. Johnson, S.G. Bear, and B.R. Maricle. 2014. A comparison of seasonal foliar chlorophyll change among ecotypes and cultivars of Andropogon gerardii (Poaceae) by using nondestructive and destructive methods. Photosynthetica 52:511-518.

Cavins, T.J., B.E. Whipker, and W.C. Fonteno. 2008. Pourthru: A method for monitoring nutrition in the greenhouse. Acta Hort. 779:289-297.

Christova-Boal, D., R. Eden, and S. McFarlane. 1996. An investigation into greywater reuse for urban residential properties. Desalination 106:391-397.

García-Valenzuela, X., E. García-Moya, Q. Rascón-Cruz, L. Herrera-Estrella, and G.A. Aguado-Santacruz. 2005. Chlorophyll accumulation is enhanced by osmotic stress in graminaceous chlorophyllic cells. J. Plant Physiol. 162:650-661.

Gilman, E.F. 1999. Pennisetum alopecuroides. Univ. Florida Fact Sheet FPS-460.

Glen, C. 2004. Salt tolerant plants recommended for Pender County landscapes. North Carolina Coop. Ext. Pender County Ctr., North Carolina State Univ., Urban Hort. Lflt. 14.

Grieve, C.M., J.A. Poss, S.R. Grattan, D.L. Suarez, S.E. Benes, and P.H. Robinson. 2004. Evaluation of salt-tolerant forages for sequential water reuse systems II: Plant-ion relations. Agr. Water Mgt. 70:121135.

Grieve, C.M. 2011. Review irrigation of floricultural and nursery crops with saline wastewaters. Isr. J. Plant Sci. 59:187-196.

Grieve, C.M., S.R. Grattan, and E.V. Maas. 2012. Plant salt tolerance, p. 405459. In: W.W. Wallender and K.K. Tanji (eds.). Agricultural salinity assessment and management. 2nd ed. ASCE Manual Rpt. Eng. Practice No. 71. Amer. Soc. Civil. Eng., Reston, VA.

Gunnell, J., J. Goodspeed, and R.M. Anderson. 2015. Ornamental grasses in the landscape: A guide for the Intermountain West. 1 June 2018. <https:// digitalcommons.usu.edu/extension curall $/ 733 />$.
Hunter, K.A. and L. Wu. 2005. Morphological and physiological response of five California native grass species to moderate salt spray: Implications for landscape irrigation with reclaimed water. J. Plant Nutr. 28:247-270.

Jull, L.G. 2009. Winter salt injury and salt-tolerant landscape plants. Univ. Wisconsin Coop. Ext. A3877.

Kirk, S. and S. Belt. 2010. Plant fact sheet for hairawn muhly (Mublenbergia capillaries). I June 2018. <https://plants. usda.gov/factsheet/pdf/fs_muca2.pdf>.

Kratsch, H., S. Olsen, L. Rupp, G. Cardon, and R. Heflebower. 2008. Soil salinity and ornamental plant selection. 1 June 2018. $<$ https://digitalcommons.usu.edu/ extension_curall/1079>.

LeCompte, J.S., A.N. Wright, C.M. LeBleu, and J.R. Kessler. 2016. Saline irrigation affects growth and leaf tissue nutrient concentration of three native landscape plant species. HortTechnology 26:309-313.

Lichtenthaler, H.K. and C. Buschmann. 2001. Chlorophylls and carotenoids: Measurement and characterization by UV-VIS spectroscopy, p. F4.3.1-F4.3.8. In: R.E. Wrolstad, T.E. Acree, H. An, E.A. Decker, M.H. Penner, D.S. Reid, S.J. Schwartz, C.F. Shoemaker, and P. Sporns (eds.). Current protocols in food analytical chemistry. Wiley, Hoboken, NJ.

McKenney, C.B., T.R. Mahato, and U.K. Schuch. 2016. Salinity tolerance of ornamental grasses adapted to semi-arid environments. Acta Hort. 1112:95-100.

Miyamoto, S. 2008. Salt tolerance of landscape plants common to the southwest. Texas Agrilife Res. TR-316.

Neill, R. 2007. Plant fact sheet for inland sea oats [(Chasmanthium latifolium (Michx.) H.O. Yates]. I June 2018. <https://plants. usda.gov/factsheet/pdf/fs_chla5.pdf>.

Niu, G. and R.I. Cabrera. 2010. Growth and physiological responses of landscape plants to saline water irrigation: A review. HortScience 45:1605-1609.

Niu, G., R. Cabrera, T. Starman, and C. Hall. 2011. Water conservation in ornamental plant production through the use of alternative water sources. HortTechnology 21:694-695.

Norcini, J.G., M. Thetford, and J.H. Aldrich. 2001. Evaluation of grasses native to Florida under low input conditions. Southern Nursery Assn. Res. Conf. Proc. 46:466-469.

Rodriguez, I.R. and G.L. Miller. 2000. Using a chlorophyll meter to determine the chlorophyll concentration, nitrogen concentration, and visual quality of st. augustinegrass. HortScience 35:751-754. 
Scheiber, S.M., D. Sandrock, E. Alvarez, and M.M. Brennan. 2008. Effect of salt spray concentration on growth and appearance of 'Gracillimus' maiden grass and 'Hameln' fountain grass. HortTechnology 18:34-38

Schiavon, M., B. Leinauer, M. Serena, B. Maier, and R. Sallenave. 2014. Plant growth regulator and soil surfactants' effects on saline and deficit irrigated warmseason grasses: I. Turf quality and soil moisture. Crop Sci. 54:2815-2826.

Schiavon, M., B. Leinauer, M. Serena, R. Sallenave, and B. Maier. 2012. Bermudagrass and seashore paspalum establishment from seed using differing irrigation methods and water qualities. Agron. J. 104:706-714.

St. John, L., D.G. Ogle, M. Stannard, and P. Pavek. 2010. Plant guide for mammoth wildrye (Leymus racemosus). I June 2018. <https://plants.usda.gov/plantguide/ pdf/pg_lera5.pdf $>$.

Strong, D., A. Todd, E. Klotz, G. Williams, E. Jones, and L. Summers. 2010. Municipal and industrial water use in Utah: "Why do we use so much water when we live in a desert?" Utah Division of Water Resources, Salt Lake City, UT.
Sun, Y., G. Niu, and C. Perez. 2015. Relative salt tolerance of seven Texas Superstar $\AA$ perennials. HortScience 50:1562-1566.

Tanji, K., S. Grattan, C. Grieve, A. Harivandi, L. Rollins, D. Shaw, B. Sheikh, and L. Wu. 2008. A comprehensive literature review on salt management guide for landscape irrigation with recycled water in coastal southern California. I June 2018. <www. salinitymanagement.org $>$.

Tomar, O.S., P.S. Minhas, V.K. Sharma, and R.K. Gupta. 2003. Response of nine forage grasses to saline irrigation and its schedules in a semi-arid climate of northwest India. J. Arid Environ. 55:533-544.

U.S. Department of Agriculture. 2002. Plant fact sheet for common rush (Juncus effusus L.). I June 2018. <https://plants. usda.gov/factsheet/pdf/fs_juef.pdf>.

U.S. Department of Agriculture. 2015. 2014 Census of horticultural specialties, Table 25. 1 June 2018. <https://www. agcensus.usda.gov/Publications/2012/ Online_Resources/Census_of Horticulture_Specialties/hortic_1_004_ 004.pdf>.

Wennerberg, S. 2004. Plant fact sheet for fox sedge (Carex vulpinoidea Michx.). 1
June 2018. <https://plants.usda.gov/ plantguide/pdf/pg_cavu2.pdf $>$.

Wright, R.D. 1986. The pour-through nutrient extraction procedure. HortScience 21:227-229.

Wu, L. and L. Dodge. 2005. Landscape plant salt tolerance selection guide for recycled water irrigation. I June 2018. <http://slosson.ucdavis.edu/Landscape Plant_Selection_Guide_for_Recycled_ Water_Irrigation/>.

Wu, S., Y. Sun, and G. Niu. 2016. Morphological and physiological responses of nine ornamental species to saline irrigation water. HortScience 51:285-290.

Wynia, R. 2007. Plant fact sheet for blue grama [Bouteloua gracilis (Willd. Ex Kunth.) Lg. ex Griffiths]. 1 June 2018. <https://plants.usda.gov/plantguide/pdf/ pg_bogr2.pdf $>$.

Zhang, Q., K. Rue, and S. Wang. 2012. Salinity effect on seed germination and growth of two warm-season native grass species. HortScience 47:527-530. 